DOI: http://doi.org/10.21698/simi.2018.ab36

\title{
THE MODULATION OF ANIONIC AND NON-IONIC SURFACTANTS BY VARIOUS BACTERIAL COMMUNITIES FROM THE ACTIVATED SLUDGE
}

$\underline{\text { Solène Borel }}{ }^{1}$, Daniel Mitru ${ }^{2}$, Catalina Stoica ${ }^{2}$, Irina Lucaciü ${ }^{2}$, Mihai Nita-Lazar $^{2}$

${ }^{1}$ ESAIP Engineering School, 18 Rue du 8 Mai 1945, 49124 Saint-Barthélemy-d'Anjou, France

${ }^{2}$ National Research and Development Institute for Industrial Ecology - ECOIND, 71-73 Drumul Podu Dambovitei, district 6, mihai.nita@incdecoind.ro, Romania

Keywords: activated sludge, anionic and non-ionic surfactants, biodegradability

\section{Introduction}

The intense use of surfactants in industry as well as in households has been generating important amount in the sewage systems and subsequently into the environment. To treat and eliminate them, wastewater treatment plants process incorporates a biodegradation treatment step based on the activated sludge. The biodegradation requires 2 levels of analysis: one chemical (measurement of surfactant concentration) and the other biochemical (measurement of COD and TSS). In this study, we performed chemical and biochemical tests, including microbiological analyses to identify the possible bacterial strains involved in biodegradation.

\section{Materials and methods}

Chemical compounds. The anionic surfactant (AS), methyl dodecylbenzene sulfonate, C19H32O3S, 99\% purity, was purchased from Merck (Darmstad,Germany) and the non-ionic surfactant (NS), nonyl phenyl polyethylene glycol, C33H60O10,99\% purity was from from Sigma Aldrich (MO, USA).

Biodegradability test. The biodegradability assay was performed during 28 days according to OECD Guideline 301, Ready Biodegradability, 301A, DOC Die-Away Test / ISO 7827. In short, two working solutions were prepared with mineral salts medium, inoculated with synthetic activated sludge $(30 \mathrm{mg} / 1 \mathrm{SS}$ or $106-108 \mathrm{cell} / \mathrm{s} / \mathrm{ml})$ and incubated in vessels, under aerobic conditions (continuous aeration and constant temperature $22^{\circ} \mathrm{C} \pm 4^{\circ} \mathrm{C}$ ).

Physico-chemical analysis. Anionic surfactants concentration was detected by EN 903:2003 method. Non-ionic surfactants concentration was detected according to ISO 7875-2:1984 method. Both chemical oxygen demand ( $\left.\mathrm{COD}, \mathrm{mgO}_{2} / \mathrm{L}\right)$ and total suspended solids (TSS, mg/l) were quantified according to ISO 6060: 1989 and EN 872:2005 methods.

Bacteria identification and quantification. Bacteria communities were identified and characterized using an Omnilog system from Biolog (CA, USA). In addition, the total number of bacteria grown at $22^{\circ} \mathrm{C}$ and $37^{\circ} \mathrm{C}$ was quantified (UFC/ml) during the all testing period. 


\section{INTERNATIONAL SYMPOSIUM "THE ENVIRONMENT AND THE INDUSTRY", SIMI 2018, BOOK OF ABSTRACTS}

\section{Results and conclusions}

The biodegradation results showed a decrease of anionic (AS) and non-ionic (NS) surfactants concentration during the time, as follows: from 7, 99 to $1,5 \mathrm{mg} / \mathrm{L}$ for NS surfactants and from 1,43 to $1,08 \mathrm{mg} / \mathrm{L}$ for AS. The overall NS removal was up to $81 \%$, but the AS was around $24 \%$, which correlated with the oxygen consumption quantified by COD method ( $75 \%$ consumption).

Table 1. The qualitative and quantitative analysis of bacterial communities' during the biodegradation test

\begin{tabular}{|c|c|c|c|}
\hline $\begin{array}{l}\text { Time } \\
\text { (days) }\end{array}$ & Sample name & $\begin{array}{c}\text { Identified bacteria / qualitative } \\
\text { analysis }\end{array}$ & $\begin{array}{c}\text { Total number of } \\
\text { bacteria /quantitative } \\
\text { analysis }\end{array}$ \\
\hline to & $\begin{array}{l}\text { Sample from the } \\
\text { activated sludge } \\
\text { (before the } \\
\text { biodegradation test) }\end{array}$ & $\begin{array}{c}\text { Acinetobacter tandoii } \\
\text { Pseudomonas aeruginosa } \\
\text { Shewanella algae } \\
\text { Bacillus simplex/butanolivorans } \\
\text { Bacillus Panaciterrea }\end{array}$ & $\begin{array}{l}1 \times 10^{9} \text { at } 22^{\circ} \mathrm{C} \\
1 \times 10^{8} \text { at } 37^{\circ} \mathrm{C}\end{array}$ \\
\hline t9 & $\begin{array}{l}\text { Sample from the } \\
\text { AS work solution } \\
\text { Sample from the } \\
\text { NS work solution }\end{array}$ & $\begin{array}{c}\text { Brevibacillus brevis } \\
\text { Pseudomonas aeruginosa } \\
\text { Bacillus pseudomycoides/cereus } \\
\text { Pseudomonas aeruginosa }\end{array}$ & $\begin{array}{l}\text { Uncountable so the } \\
\text { concentration in bacteria } \\
\text { increase a lot }\left(>10^{10}\right)\end{array}$ \\
\hline$t 15$ & $\begin{array}{l}\text { Sample from the } \\
\text { AS work solution } \\
\text { Sample from the } \\
\text { NS work solution }\end{array}$ & $\begin{array}{c}\text { Acinetobacter aminovorans } \\
\text { Pseudomonas aeruginosa } \\
\text { Bacillus cereus } \\
\text { Pseudomonas aeruginosa }\end{array}$ & $\begin{array}{l}36 \times 10^{5} \text { at } 22^{\circ} \mathrm{C} \\
28 \times 10^{5} \text { at } 37^{\circ} \mathrm{C} \\
31 \times 10^{5} \text { at } 22^{\circ} \mathrm{C} \\
26 \times 10^{5} \text { at } 37^{\circ} \mathrm{C}\end{array}$ \\
\hline
\end{tabular}

The analysis of bacterial communities indicated a high diversity and elevated number of bacteria at the beginning of the test ( $\mathrm{t} 0$ ) in the activated sludge sample (Table 1 ). After several days of incubation, the bacterial growth was robust (the number of bacteria increased) as well as the community structure of bacteria. Then, the decrease observed between t9 t15 confirms the level of consumption of oxygen and nutritive resources (decline phase). During the incubation time, Shewanella algea failed to adapt of the new conditions (due to surfactants concentration), but Pseudomonas aeruginosa adapted very well and prevailed over the entire bacterial population during the testing period (Table 1).

The decrease of the COD and the fluctuation curve of the TSS showed an active biodegradation process of surfactants and a possible change of the bacterial structural community. Overall, Pseudomonas aeruginosa, based on its major presence throughout the incubation period, could play a major role in AS and NS biodegradation.

\section{Acknowledgments}

This work was carried out within a two months internship based on the Work placement Agreement between INCD ECOIND, Romania and ESAIP School, France. 